UDC 811.111'42

DOI https://doi.org/10.32841/2409-1154.2021.51-3.1

\author{
Balatska O.L., \\ PhD, Associate Professor, \\ Associate Professor, Department of general linguistics and foreign languages, \\ National University "Yuri Kondratyuk Poltava Polytechnic"
}

Kuznetsova Yu. I.,

PhD, Associate Professor, Associate Professor, Department of general linguistics and foreign languages, National University "Yuri Kondratyuk Poltava Polytechnic"

\title{
MEANS OF NEGATIVE EVALUATION IN CRITICAL REMARKS IN ENGLISH-LANGUAGE RESEARCH ARTICLES IN SOCIAL STUDIES
}

\begin{abstract}
Summary. The article studies mean of negative evaluation in critical remarks in English-language research articles in social studies, which are considered to represent one of the types of the leading genre of English-language scientific discourse, i.e. the article. Materials of our research consist of 112 critical remarks obtained from 50 English-language research articles in social studies which were published in scientific journals of the UK and the USA in 2009-2011. It has been found out that negative evaluation in criticism in English-language research articles in social studies can be expressed explicitly and implicitly. The explicit way of expressing negative evaluation is carried out with markers, i.e. lexical and lexico-grammatical means of negative evaluation. Lexical means of expressing negative evaluation are linguistic units used for negative evaluation, among which were recorded nouns, adjectives, verbs, and adverbs. Our research has demonstrated that nouns and adjectives have higher per-
\end{abstract} centage of using in criticism, while verbs and adverbs have considerably lower percentage of using. Explicit lexico-grammatical means of negative evaluation have been divided into several types, among which negation of the predicate of the sentence, negation of the object and negation of the subject are usually used. That is performed by means of using negators. In particular, predicate negation is a type of explicit lexico-grammatical means of expressing negative evaluation which is used the most often. Whereas object negation and subject negation are less numerous in critical remarks. They use the implicit way of negative evaluation by verbalizing indicators of implicit meaning, i.e. linguistic units which have positive or neutral semantics and give negative semantics to an utterance together in the context. As a rule, implicit means of expressing negative evaluation have future meaning or denote the need for performing further research. The results of this study have shown that explicit means of expressing negative evaluation are more numerous in critical remarks in English-language research articles in social studies than implicit means of negative evaluation. It should also be mentioned that as far as the types of explicit means of expressing negative evaluation in critical remarks in English-language research articles in social studies are concerned, explicit lexical means of expressing negative evaluation are used more often than lexico-grammatical means.

Key words: English-language scientific discourse, genre, research article in social studies, criticism, critical remark, means of negative evaluation.
Introducing the problem. Nowadays, the attention of linguists is focused on the study of various aspects of English-language scientific discourse [1-3]. This can be explained by the fact that the English language has acquired the status of the international language of communication (lingua franca) [4-6], in particular that of science, and science itself has become extremely important for the development of modern society. Taking into consideration mentioned above, scholars analyze genres of English-language scientific discourse $[7 ; 8]$, the leading genre among which we consider to be a research article $[7 ; 8]$. As a rule, an English-language research article contains such an important component for the development of science as criticism which is verbalized in the text of the corresponding research article in critical remark(s).

Analysis of the previous literature. Criticism in scientific discourse has already been studied by modern linguistic scholars [9-19]. However, despite its importance for the development of science and availability of scientific works that analyze the means of expressing negative evaluation in criticism in general [20-23], the means of expressing negative evaluation in criticism in English-language research articles in different academic disciplined need further research.

The purpose of the research. Taking into account the growing need for Ukrainian sociologists to publish their research articles in English-language foreign journals, the purpose of this research was to explore the means of expressing negative evaluation in English-language research articles in social studies.

Materials and methods. The problem has been studied using a corpus of 112 critical remarks containing 292 critical utterances obtained from 50 research articles in social studies. The research articles were published in electronic journals of the United Kingdom and the USA during 2009-2011.

The research methodology includes definitive analysis, component analysis, interpretive-textual analysis, quantitative analysis and the method of cognitive-discursive interpretation.

The main body. The analysis of the material has demonstrated that the axiological content of criticism/critical remarks (CRs), namely negative evaluation, in modern English-language research articles in social studies can be expressed explicitly or implicitly.

In case of using the explicit method of negative evaluation (67.87\% of all means of expressing negative evaluation in CRs in 
English-language research articles in social studies), negative evaluation is expressed by means of using lexical or lexico-grammatical means, which allows us to distinguish two types of CRs in which negative evaluation is expressed explicitly.

Thus, the first type of CRs with explicit expression of negative evaluation includes CRs in which the negative evaluation is verbalized through the use of explicit lexical means of negative evaluation (54.88\% of all CRs in English-language research articles in social studies).

As a result of the word class analysis of explicit lexical means of negative evaluation in CRs in English-language research articles in social studies, it was revealed that they include the following:

- nouns (38.5\% of all explicit lexical means) (drawback, lack, limitation, disregard, flaw, gap, neglect, problem, paucity, shortcoming, weakness, etc.), e.g.:

(1) However, there is a gap in the current research regarding what motivates users to join in the online melee and how the real world and the online world interact with each other.

- adjectives $32.5 \%$ of all explicit lexical means of negative evaluation) (limited, difficult, inadequate, scarce, insufficient, negative, unclear, scant, unreliable, etc.), e.g.:

(2) Research on the practice of law is scarce because most academic lawyers are not trained in empirical research methods.

- verbs (22.3\% of all explicit lexical means of negative evaluation) (ignore, lack, neglect, exaggerate, limit, overlook, etc.), e.g.:

(3) $<\ldots>$ these forms of social capital have often been overlooked by mainstream society because they do not fit into the dominant, capitalistic cultural value system.

- adverbs (6.7\% of all explicit lexical means of negative evaluation) (incorrectly, hardly any, inappropriately, only, rather (than)), e.g.:

(4) Further, it is possible that research to date has inappropriately specified the relationship between OTC, and other drug misuse.

In addition, negative evaluation in CRs in English-language research articles in social studies can be expressed through the use of explicit lexico-grammatical means, that makes the second type of expressing negative evaluation in CRs in English-language research articles in social studies, where we observe the use of negative operators-negators together with lexical units with negative or neutral semantics [1] (13.09\% of all means of expressing negative evaluation in CRs in the English-language research articles in social studies).

The results of our analysis demonstrated that in CRs in the English-language research articles in social studies, negation of the prediate is used the most often $(76.95 \%$ of all lexico-grammatical means of expressing negative evaluation in CRs in the English-language research articles in social studies), which is carried out through the use of a negator, that is the negative particle not $(n ' t)$.

In CRs in English-language research articles in social studies, negation of the predicate can be performed according to two models.

The first model is presented by the negation of the compound verbal predicate $(67.9 \%$ of all CRs in the English-language research articles in social studies, which use the predicate negation for negative evaluation) is usually implemented in the following modifications:

- Auxiliary verb have for Present Perfect + not + notional verb, e.g.:
(5) The number of field hours required within a practicum placement has not been explored on a national level, perhaps in part because CSWE sets a minimum standard of 900 hours.

- Auxiliary verb do for Present Simple or Past Simple + not + notional verb, e.g.:

(6) Although this study does not contain a comparison with young adults in intact families, the findings add complexity to past research investigating the relationship between divorce and gender attitudes.

- Modal verb + not + notional verb, e.g.:

(6) The specific characteristics of those willing to share their experiences certainly may not be representative of those typically on OPC orders.

The second model is represented by CRs with negation of a compound nominal predicate (32.1\% of all CRs with negation of the predicate), that is the verb be in the form of Present Simple or Past Simple + not + the nominal part represented by an adjective or a participle II, e.g.:

(8) However, even the statistical significance of this particular finding was not strong.

The CRs in English-language research articles in social studies can also use object negation for negative evaluation $(16.79 \%$ of all lexico-grammatical means of negative evaluation in CRs) by means of using the negative pronoun no, which is carried out according to the model: (formal) subject + be, etc. + no + object, e.g.:

(9) There were no national studies found that looked at how students proceed through the field placement process, although recommendations are made for the use of student and agency questionnaires to streamline and systematize the process.

In CRs in the English-language research articles in social studies we have also recorded negation of the subject ( $8.8 \%$ of all CRs with lexico-grammatical means of negative evaluation), which is implemented according to the model: negator (no, not) + subject, e.g.:

(10) In addition, no survey data is available for students who were absent the day the survey was administered.

As it was mentioned above, negative evaluation in CRs in English-language research articles in social studies can also be expressed implicitly $(32.13 \%$ of all means of expressing negative evaluation in criticism in the English-language research articles in social studies). In order to do that authors of the English-language research articles in social studies use:

- linguistic units with future meaning in combination with verbs/modal verbs that indicate the need for further research, e.g.:

(11) Therefore, further research is needed to explore similar methods of data collection.

- nouns and verbs that indicate the need for further research, e.g.:

(12) Although a qualitative comparison between our sample and the remaining RFS participants was beyond the scope of this exploratory study, these issues need to be examined more closely.

- linguistic units with future meaning in combination with adjectives that indicate the need for further research:

(13) Further research in this area is necessary to determine how to implement these programs in schools and develop successful applications for age-specific, population-specific, and skill-specific interventions.

- interrogative sentences: 
(14) Further research is needed to explore if and how differences in the structure of the field practicum impacts learning outcomes. Do programs with field seminars better prepare students than those that do not? Is it an advantage when field liaisons also lead field seminars? Do hour requirements impact the development of basic competencies?

- other linguistic units with positive or neutral semantics, which together in the context give negative semantics to the utterance, e.g.:

(15) While observers will sometimes recognize that New Orleans was declining in population and facing many problems before the storm (see, for example, Fussell 2007), most commentators have tended to concentrate on the changes brought about by the hurricane and on reconstructing from the hurricane.

Conclusions. Thus, the performed analysis makes it possible to conclude that the means of expressing negative evaluation in criticism in English-language research articles in social studies are quite diverse. The explicit way of expressing negative evaluation is used more often than the implicit way of negative evaluation. In addition, explicit lexical means of expressing negative evaluation are significantly more numerous than explicit lexico-grammatical means.

Further research can be carried out to analyze the means of negative evaluation in criticism in English-language research articles from other academic disciplines.

\section{References:}

1. Ільченко О.М. Етикет англомовного наукового дискурсу. Київ : Політехніка, 2002. 288 с.

2. Hyland K. Academic Discourse: English In A Global Context. Bloomsbury, 2009. 256 p.

3. Hyland K. Disciplinary discourses: Social interactions in academic writing. Michigan : University of Michigan Press, 2004. 211 p.

4. Ljosland R. English as an Academic Lingua Franca: Language policies and multilingual practices in a Norwegian university. Journal of Pragmatics. 2011. Volume 43, Issue 4. P. 991-1004.

5. Jenkins J. English as a Lingua Franca: Attitude and Identity. Oxford : Oxford University Press, 2007. 284 p.

6. Mauranen A., Ranta E. English as a Lingua Franca: Studies and Findings. Cambridge Scholars Publishing, Cambridge Scholars, 2010. $385 \mathrm{p}$.

7. Яхонтова Т.В. Лінгвістична генологія наукової комунікації. Львів : ЛНУ ім. І. Франка, 2009. 420 с.

8. Swales J.M. Genre Analysis: English in Academic and Research Settings. Cambridge : Cambridge Univ. Press, 1990. 260 p.

9. Crossed Words: Criticism in Scholarly Writing / Ed. Françoise SalagerMeyer, Beverly A Lewin. Peter Lang Publishing, Incorporated, 2011. $371 \mathrm{p}$.

10. Salager-Meyer F. Rhetorical evolution of oppositional discourse in French academic writing. Hermes, Journal of Linguistics. 2000. No. 25. P. 23-48.

11. Salager-Meyer F., Alcaraz Ariza M.A., Zambrano N. The scimitar, the dagger, and the glove: Intercultural differences in the rhetoric of criticism in Spanish, French, and English medical discourse. English for Specific Purposes. 2003. No. 22. P. 223-247.

12. Fagan A., Martin Martin P. The use of critical speech acts in psychology and chemistry research papers. Iberica. 2004. No. 8. P. 125-137.

13. Giannoni S. Negative Evaluation in Academic Discourse. A Comparison of English and Italian Research Articles. Linguistica e Filologia. 2005. No. 20. P. 71-99.

14. Гаврилова Н.В. Лингвокультурный концепт «КРИТИКА» и его функционирование в педагогическом дискурсе : автореф. дис. на соискание уч. степени канд. филол. наук : спец. 10.02.19 «Теория языка». Волгоград, 2007. 20 с.
15. Moreno A.I., Suarez L. A study of critical attitude across English and Spanish academic book reviews. Journal of English for Academic Purposes. 2008. No. 7. P. 15-26.

16. Mur-Dueñas P. Critical Acts in Published and Unpublished Research Article Introductions in English: A Look into the Writing for Publication Process. International Advances in Writing Research: Cultures, Places, Measures. Parlor Press. The WAC Clearinghouse. 2012. P. 403-420. URL: http://wac.colostate.edu/books/wrab2011/.

17. Moreno A.I., Suarez L. Academic book reviews in English and Spanish: Is "giving reasons for critical comments" a universal politeness strategy? Constructing Interpersonality: Multiple Perspectives and applications to written academic discourse / Ed. by R. Lorés-Sanz, P. Mur-Dueñas, E. Lafuente-Millán. Cambridge : Cambridge Scholars, 2010. P. 137-160.

18. Salager-Meyer F. From Self-Highlightedness to Self-Effacement: A Genre-Based Study of the Socio-Pragmatic Function of Criticism in Medical Discourse. LSP \& Professional Communication. 2001. Volume 1, Number 2. P. 63-84.

19. Salager-Meyer F. The rationale behind academic conflict: from outright criticism to contextual 'niche' creation. UNESCO-ALSED-LSP. 1998. No. 21(2). P. 4-23.

20. Балацька О.Л. Дискурсивні властивості критики в англомовній науковій статті : автореф. дис. ... канд. філол. наук : спец. 10.02.04 «Германські мови». Харківський національний університет імені В.Н. Каразіна. Харків, 2013. 20 с.

21. Балацька О.Л. Експліцитні лексико-граматичні засоби актуалізації аксіологічного змісту у критичних зауваженнях англомовної наукової статті. Наукові записки. Випуск 130. Серія: Філологічні науки (мовознавство). Кіровоград : РВВ КДПУ ім. В. Винниченка, 2014. С. 218-221.

22. Балацька О.Л. Експліцитні лексико-граматичні засоби актуалізації аксіологічного змісту у критичних зауваженнях англомовної наукової статті. Наукові записки. Кіровоград : РВВ КДПУ ім. В. Винниченка, 2014. Випуск 130. Серія: Філологічні науки (мовознавство). С. 218-221.

23. Балацька О.Л. Імпліцитні засоби вираження негативної оцінки у критичних зауваженнях англомовної наукової статті. Вісник Харківського наиіонального університету імені В.Н. Каразіна. Харків : ХНУ імені В.Н. Каразіна, 2014. № 1102. С. 24-28.

Балацька О. Засоби актуалізації негативної оцінки у критичних зауваженнях в англомовних наукових статтях із соціологічних дисциплін

Анотація. У наведеній статті інвентаризуються засоби вираження негативної оцінки у критичних зауваженнях в англомовних наукових статтях із соціологічних дисциплін, тобто в одному 3 видів провідного жанру сучасного англомовного наукового дискурсу - статті. Матеріалом цього дослідження були 112 критичних зауважень, які загалом містять 292 критичних висловлювання, відібраних із 50 статей із соціологічних дисциплін, опублікованих в електронних наукових журналах Великої Британії та США протягом 2009-2011 pр. У роботі показано, що негативна оцінка у критиці може бути актуалізована як експліцитно, так і імпліцитно. У разі застосування 3 цією метою експліцитного способу вербалізації негативної оцінки використовуються маркери - лексичні й лексикограматичні засоби актуалізації негативного змісту. Лексичні засоби - мовні одиниці, які застосовуються для вербалізації негативної оцінки, серед котрих зареєстровано було іменники, прикметники, дієслова, а також прислівники. Аналіз матеріалу показав, що серед експліцитних лексичних засобів вербалізації негативної 
оцінки іменники та прикметники мають більшу питому вагу, ніж дієслова та прислівники. Експліцитні лексикограматичні засоби актуалізації негативної оцінки, серед яких можна виокремити декілька типів, застосовуються у меншій кількості випадків і переважно представлені запереченням присудка, додатка та підмета, що здійснюється за допомогою використання відповідних негаторів. Зокрема, заперечення присудка із зазначеною метою використовується частіше, ніж заперечення підмета чи додатка. Імпліцитний спосіб вираження негативної оцінки у статтях зазначеного типу реалізується у критичних зауваженнях завдяки застосуванню мовних одиниць, які мають позитивну або нейтральну семантику та які в контексті у своїй сукупності надають відповідному висловленню негативне оцінне значення. Зазвичай для цього у критичних зауваженнях в англомовних наукових статтях із соціологічних дисциплін використовують мовні одиниці, які мають футуральну семантику, у поєднанні 3 мовними одиницями, що вказують на необхідність проведення подальшого дослідження. Крім того, було виявлено, що експліцитний спосіб вираження негативної оцінки має більшу питому вагу, ніж імпліцитний спосіб.

Ключові слова: англомовний науковий дискурс, жанр, наукова стаття із соціологічних дисциплін, критика, критичне зауваження, засоби вираження негативної оцінки. 